Western New England University School of Law

Digital Commons @ Western New England University School of Law

Faculty Scholarship

Faculty Publications

2012

\title{
Inside-Out as Law School Pedagogy
}

Giovanna Shay

Western New England University School of Law, gshay@law.wne.edu

Follow this and additional works at: http://digitalcommons.law.wne.edu/facschol

Part of the Civil Rights and Discrimination Commons, and the Criminal Law Commons

\section{Recommended Citation}

Giovanna Shay, Inside-Out as Law School Pedagogy, 62 J. LEGAL EDUC. 207 (2012).

This Article is brought to you for free and open access by the Faculty Publications at Digital Commons @ Western New England University School of Law. It has been accepted for inclusion in Faculty Scholarship by an authorized administrator of Digital Commons @ Western New England University School of Law. For more information, please contact pnewcombe@law.wne.edu. 


\title{
Inside-Out as Law School Pedagogy
}

\author{
Giovanna Shay
}

In the fall of 20IO, and again in spring 2012, I taught a course entitled Gender \& Criminal Law inside the Western Massachusetts Correctional Alcohol Center in Springfield. Participants in the course included roughly equal numbers of law students from my home academic institution, Western New England University School of Law (WNE), and residents of the facility. For fourteen weeks, we met on Friday mornings at the institution to discuss issues including domestic violence law reform, the role of family ties in sentencing, and gender issues in prisoner reentry.

I taught my course in a modified form of the Inside-Out format. Inside-Out is a national training program founded by Lori Pompa and based at Temple University. It offers training programs several times each year. The program has trained more than 300 instructors to date who have offered 300 Inside-Out courses around the U.S. and in Canada. ${ }^{1}$ Most of these instructors are college professors who typically teach undergraduates. I participated in training in summer 2009, becoming the first law school professor to join the Inside-Out network. ${ }^{2}$

This Essay reflects on my Inside-Out experience. It makes the case for Inside-Out as a particularly useful form of experiential learning for law students. It also describes some techniques that I learned through teaching an Inside-Out course that can be implemented in a more traditional law school setting.

Others contributing to this symposium have constructed different vehicles designed to promote exchange between law students and incarcerated people. We have assembled this collection because we believe that the legal academy has a role to play in examining the nation's over-reliance on incarceration.

Giovanna Shay is a Professor of Law, Western New England University School of Law. Thanks to everyone at Inside-Out, all of my students, our hosts at the facility, and my colleagues at Western New England University School of Law, particularly our Associate Dean for Academic Affairs, Beth Cohen. Thanks too to James Forman, Jr. for commenting on an earlier draft, and to Kristin Bumiller for visiting our class and providing helpful guidance.

I. The Network, College of Liberal Arts Temple University (20ro), available at http://www. insideoutcenter.org/national-presence.html.

2. Villanova University School of Law has subsequently offered an Inside-Out course, and at the time of the writing of this article, law professors at schools including Yale and Notre Dame also had completed Inside-Out training. 


\section{Why Inside-Out?}

After several years of teaching criminal law and related electives in a traditional law school format, I began looking for ways to enrich my curriculum. I came to teaching after practicing as a public defender, and held a clinical teaching fellowship before transitioning to podium teaching. Although I absolutely believed in the value of learning "to think like a lawyer" through case analysis, I also saw that my students' views were heavily shaped by their life experiences and intuition. I thought that they would be betterprepared lawyers if they had more direct exposure to the criminal punishment system. ${ }^{3}$

I was considering the idea of approaching a correctional facility to develop a collaborative project when I met Amherst College Professor Kristin Bumiller. She told me that a group of professors was already doing what I was considering-through the Inside-Out network. I visited Kristin's Inside-Out class, offered at the county jail in Northampton, Massachusetts, and I enrolled in training.

Soon I found myself at a retreat center outside of Philadelphia in an intense week-long training program that included time in the Philadelphia jails and at Graterford prison. At Graterford, we participated in a two-day mini version of an Inside-Out course, led by a group of experienced "inside" students, alumni of the program. (In Inside-Out nomenclature, the incarcerated students are "inside" students, and the free world students are "outside" students).

It may be easy to guess why Inside-Out is valuable to the incarcerated. There are an unprecedented number of incarcerated people in the United States-currently 2.3 million. ${ }^{4}$ Most of them have received a grossly inadequate education. 5 Despite this tremendous need, incarcerated students are restricted from receiving many important sources of funding for education, such as federal Pell grants. ${ }^{6}$

3. I will follow the example of Teri Miller, Dean Spade and others by using the term "criminal punishment system" rather than "criminal justice system." See, e.g., Teresa A. Miller, Lessons Learned, Lessons Lost: Immigration Enforcement's Failed Experiment with Penal Severity, $3^{8}$ Fordham Urb. L.J. 217 (2010); Dean Spade, Keynote Address: Trans Law Reform Strategies: Co-Optation, and the Potential for Transformative Change, 30 Women's Rts. L. Rep. 288 (2009).

4. Incarceration, The Sentencing Project, available at http://www.sentencingproject.org/ template/page.cfm?id=IO7.

5. U.S. Dept. of Education Office of Education \& Research, Literacy Behind Prison Walls: Profiles of the National Adult Literacy Survey at xviii (Oct. 1994) (finding that seven of ten inmates perform at the lowest two levels of literacy, as measured on a five-level instrument).

6. Daniel Karpowitz \& Max Kenner, Education as Crime Prevention: The Case for Reinstating Pell Grant Eligibility for the Incarcerated at 7, Bard Prison Initiative, available at https://www. stcloudstate.edu/continuingstudies/distance/documents/EducationasCrimePrevention TheCaseForReinstatingthePellGrantforOffendersKarpowitzandKenner.pdf (writing that the number of post-secondary education programs for the incarcerated in New York State fell from 70 to 4 after the abolition of Pell grants to the incarcerated in r994); Laura E. Gorgol \& Brian A. Sponsler, Unlocking Potential: Results of a National Survey of Post-Secondary 
The racial disparities in incarceration ${ }^{7}$ make this educational divide morally intolerable. Commentators describe a racialized "school-to-prison-pipeline," in which sub-standard free-world education and harsh criminal punishment policies work together to produce synergistic, subordinating effects. ${ }^{8}$

There are also pragmatic reasons why education for the incarcerated benefits the free world. The vast majority of the incarcerated will be released. ${ }^{9}$ Studies suggest that schooling may reduce recidivism. ${ }^{\text {I0 }}$ One 1997 study for the U.S. Department of Education reported that participating in some type of schooling while incarcerated reduced the risk that a student would return to prison by 29 percent."

But these are not the reasons that I decided to teach a law course in an Inside-Out format. I did it because I believed it was invaluable for the law students. My hope is that the law students will draw on this experience in their legal careers. Today's law students someday will be in a position to make many decisions-as prosecutors, defense attorneys, judges, legislators, and

Education in State Prisons at 2, 6-8, I8 (May 20II), available at https://www.widernet.org/ sites/default/files/Unlocking_Potential-PSCE_FINAL_REPORT_May_2orr.pdf (noting that the number of post-secondary correctional education programs had rebounded to pre-I994 levels by 2005, and that some federal sources of funding had been made available to youth offenders, but still concluding that "incarcerated persons are ineligible for nearly all federal and state need-based financial aid programs").

7. Racial Disparity, The Sentencing Project, http://www.sentencingproject.org/template/ page.cfm?id=I22 (reporting that African-American and Latino prisoners comprise 6o percent of U.S. inmates).

8. See Katayoon Majd, Students of the Mass Incarceration Nation, 54 Howard L.J. 343, 34647 (20II) (arguing that "the education and justice systems . . . have developed a 'symbiotic relationship,' effectively working together to lock out large numbers of youth of color from societal opportunity and advantage") (internal citations omitted). See, e.g., NAACP, Misplaced Priorities: Over-Incarcerate, Under-Educate (Apr. 20II) (drawing a direct connection between increased state spending on prisons and reduced resources for schools for poor children of color).

9. Gorgol \& Sponsler, supra note 6, at i6 (estimating that 95 percent of prisoners will return to the free world); Justin Brooks, Addressing Recidivism: Legal Education in Correctional Settings, 44 Rutgers L. Rev. 699, 702-05 (1992).

Io. Karpowitz \& Kenner, supra note 6, at 4-6; see Gregory A. Knott, Cost and Punishment: Reassessing Incarceration Costs and the Value of College-in-Prison Programs, 32 N.Ill. U.L. Rev. 267, 268 (2012) (arguing that "college-in-prison programs are an effective response to prison population growth and costs explosions."); Michelle Fine et al., Changing Minds: The Impact of College in a Maximum Security Prison (Sept. 200I) (reporting that "women who attended college while in prison [at Bedford Hills] were significantly less likely to be reincarcerated (7.7 percent) than those who did not attend college while in prison (29.9 percent)"); Correctional Education Association, Education Reduces Crime: Three-State Recidivism Study (2003) (demonstrating statistically significant lower rates of recidivism for participants in corrections education in Ohio and Minnesota); Sylvia G. McCollum, Prison College Programs, 73 The Prison Journal 5I, 58-59 (1994) (listing studies that suggest a lower recidivism rate for prisoners who have completed educational programs while incarcerated).

II. Karpowitz \& Kenner, supra note 6, at 4 n.7 (quoting Steurer, Smith \& Tracy, The Three State Recidivism Study, U.S. Department of Education (I997)). 
state attorneys general. Their choices can greatly impact the administration of our criminal stigma systems. I wanted future lawyers to view people in the criminal punishment system as human beings, and to understand all of the costs of incarceration. ${ }^{12}$

It took some time to find the right facility. In western Massachusetts, InsideOut is so popular among undergraduate professors that it is difficult to find a space in which to teach. Institutions have limited facilities in which classes can meet, and at some correctional institutions, there is considerable turnover, or only a small number of inmates with educational qualifications sufficient to take advantage of the opportunity. I approached a few institutions before being referred by a correctional administrator to the facility where I taught. I was lucky to find a facility with a welcoming staff. It is a secure, residential facility, but also a permeable facility in the sense that most residents leave four days per week for work release. We met on Friday mornings, when residents are typically in programming.

\section{What is Inside-Out?}

Founder Lori Pompa credits a Pennsylvania prisoner with suggesting the idea for an ongoing Inside-Out program. In 1995, Lori took Temple students on a day trip to a Pennsylvania prison. After a compelling discussion between college students and inmates, a prisoner there suggested continuing the conversation and making it permanent. ${ }^{3}$ She started teaching at the Philadelphia jails in 1997. ${ }^{14}$ Ultimately, Inside-Out spread to the Pennsylvania State Correctional Institution at Graterford, where a standing group of inside alumni functions as a "think tank," providing direction for the program. ${ }^{15}$ Meanwhile, other Temple professors began teaching in an Inside-Out format. In 2003, Pompa was awarded a Soros Justice Fellowship to conduct national training workshops to replicate the program. ${ }^{16}$ Today, more than 3 oo professors from 150 institutions have been trained, offering 300 Inside-Out courses that have involved I0,00o students. ${ }^{17} \mathrm{~A}$ list serve connects professors across

I2. Cf. James Forman, Jr., Why Care About Mass Incarceration?, ro8 Mich. L. Rev. 993, Ioo7 (20IO) (arguing that "America's prison policies hurt us all" because prisons have too little education and too much "violence and unnecessary degradation").

I3. The Inside-Out Timeline, College of Liberal Arts Temple University (20Io), available at http://www.insideoutcenter.org/timeline.html; see Lori Pompa, Service-Learning as Crucible: Reflections on Immersion, Context, Power, and Transformation, 9 Mich. J. Comm. Service Learning 67 (2002).

I4. Inside-Out Timeline, College of Liberal Arts Temple University (20I0), available at http:// www.insideoutcenter.org/timeline.html.

I5. Id.

I6. The Network, College of Liberal Arts Temple University (20I0), available at http://www. insideoutcenter.org/national-presence.html.

I7. Id. 
disciplines and institutions, all of whom are interested in issues of education and incarceration.

Pompa sometimes describes Inside-Out by explaining what it is not. ${ }^{18}$ It is not "an opportunity to do research," "an opportunity for charity," "a "scared straight' program," "a whistle-blowing program," or "a vehicle for developing relationships that will exist outside of the parameters of the program." Inside-Out requires semi-anonymity (first names only) for all participants, and forbids contact between inside and outside students outside of the classroom (e.g., no phone calls, no visits, no letters).

Although Inside-Out aspires to improve the educational attainment of those who are imprisoned, and some Inside-Out courses offer college credit through cooperating institutions to inside students, traditional correctional education is not its main focus. Other well-regarded programs strive primarily to educate the incarcerated. The Bard Prison Initiative, founded in I999 at Bard College, offers B.A. and A.A. degree programs to the incarcerated at five prison campuses in New York. ${ }^{20}$ Bard College students volunteer through the program. ${ }^{21}$ The Wesleyan Center for Prison Education offers courses at Connecticut institutions. ${ }^{22}$ In the District of Columbia, David Domenici and James Forman, Jr. founded the Maya Angelou Academy, a model educational program for incarcerated juveniles, in which Forman, a law professor, involved Georgetown law students. ${ }^{23}$

By contrast, Inside-Out is designed as a "transformative" educational experience. ${ }^{24}$ It is described as an "embodied experience," meaning that the learning that occurs is not solely cerebral. ${ }^{25}$ Outside students gain personal experience of the criminal punishment system by placing themselves in new and sometimes uncomfortable settings. Outside students actually experience some corrections routines; they meet officers and inmates; they take classes

I8. Clarifications, College of Liberal Arts Temple University (2010), available at http://www. insideoutcenter.org/clarification.html.

I9. Id.

20. Bard Prison Initiative, Bard College, available at http://www.bard.edu/bpi/; see Daniel Karpowitz, Prison, College, and the Paradox of Punishment, in Crime and Punishment: Perspectives From the Humanities 305-33I (Austin Sarat, ed., Elsevier 2005) (special volume 37 of Studies in Law, Politics, and Society).

2I. Bard Prison Initiative, Bard College, available at http://www.bard.edu/bpi/.

22. http://www.wesleyan.edu/cpe/.

23. David Domenici \& James Forman, Jr., What it Takes to Transform a School Inside a Juvenile Justice Facility: The Story of the Maya Angelou Academy, in Justice for Kids: Keeping Kids Out of the Juvenile Justice System, at $28_{3}$ (Nancy Dowd, ed., NYU Press 20II); Karen Houppert, School of Second Chances, Wash. Post Magazine, Apr. I2, 2009.

24. See, e.g., Lori Pompa, Breaking Down the Walls: Inside-Out Learning and the Pedagogy of Transformation, in Challenging the Prison-Industrial Complex, at 253-272 (Stephen John Hartnett, ed., Univ. of Illinois Press 20II).

25. Philosophy, College of Liberal Arts Temple University (2010), available at http://www. insideoutcenter.org/philosophy.html. 
within rooms at the correctional facility; they talk with prisoners about the experience of incarceration. The goal is for inside and outside students to re-examine their pre-existing notions about crime and punishment through conversation with one another. ${ }^{26}$ Pompa's goal in creating the program was to spur students to question-to ask who is incarcerated, how the system operates, and what students might do to change it. ${ }^{27}$

Inside-Out is not about advocacy to change conditions in correctional facilities, or about political activism. In my previous work, I had functioned as an attorney, and, later, as a teacher for future advocates. However, I was willing to forego my accustomed lawyer role in order to create this educational experience for law students. And although I see the importance of political engagement to reduce the nation's reliance on incarceration, I am willing to invest in dialogue and experiential learning to promote change in the longterm.

In my course, I expressly addressed the potentially exploitative aspects of the program. One concern that can surface is what tangible benefit inside students gain if they are not receiving course credit. The converse question is why the inside students should receive a free course, when outside students pay tuition. My response to both these questions is that the program has intrinsic intellectual and experiential value for both groups of participants. Students have to judge for themselves whether it is worth it.

Another controversial aspect of Inside-Out is the facility tour. The typical curriculum provides for a tour of the institution for outside students during the course. Some view this as intrusive and voyeuristic, while others argue that it is an integral part of the experience for the outside students. The first semester that I offered the course, our outside group made the decision not to tour the facility, a choice that I maintained the second semester that I taught. Instead, we invited the inside students, accompanied by our facility liaison, to visit WNE for our penultimate class. Our academic dean greeted our guests; we held class in our moot courtroom; and the law students hosted a potluck for our inside colleagues. The campus meeting was so successful that we repeated it when I offered the course a second time. This facet of our semester is one advantage of teaching in a permeable, low-security facility.

\section{Teaching Law in an Inside-Out Format}

Inside-Out courses are typically undergraduate classes. They cover a wide range of subject areas (although many do address some aspect of criminal punishment). ${ }^{28} \mathrm{My}$ course was different because it was a class in the law. Not

26. Id.

27. Pompa, supra note 13 , at 67 .

28. Id. at 259 (describing "dozens" of courses in "many and varied disciplines"); see Simone Weil Davis, Inside-Out: The Reaches and Limits of a Prison Program, in Razor Wire Women, at 203 (Jodie Michelle Lawston \& Ashley E. Lucas, eds., SUNY Press 20II) (describing a writing course in an all-women's facility, involving "outside" students from a women's liberal arts college, that focused on therapeutic writing). 
surprisingly, there were many challenges to teaching a law school course, including traditional law students, in a correctional facility. How much reading should I assign? What should I select as an entry point for discussion? How much background should I provide to the legal doctrines discussed in the cases?

I chose to adapt my Gender \& Criminal Law course to an Inside-Out format. In the traditional law school classroom, the first half of the story is devoted to two feminist law reform efforts-rape law and domestic violenceand critiques of those movements, from the right and the left. The second half of the traditional seminar is devoted to issues of gender in sentencing and corrections.

For the Inside-Out version, I modified my materials in a number of ways. I eliminated the rape law reform movement unit, because I did not want to begin with a topic that is so fraught in an environment that is inherently sensitive, and in which we were building trust. Since we met once per week in a longer class (to reduce travel time and time lost to security checks), I consolidated units. I reduced the amount of reading somewhat, but not significantly. For each unit, I continued to assign a couple of cases, as well as some very short (and I hoped provocative) excerpts from law review articles. Like in my traditional course, I required response papers. The first time I taught InsideOut, I required these papers of a couple of discussion leaders each week. I found the reflection papers to be so helpful in promoting engagement that the second time around, I asked all students to write a reflection paper every week As I do in some first-year courses, I posted reflection questions designed to direct the students to the most important concepts in the reading.

The second time I taught Inside-Out, I hired one of the law students who had completed the course the previous year as my Research and Teaching Assistant. He visited the facility a couple of times per week outside of regular class hours, to support inside students with their writing.

I did some additional framing for the Inside-Out version of the course. The model Inside-Out curriculum suggests that the inside and outside groups meet separately the first week, to receive an orientation to the rules. The second class is the first meeting of the two groups, which includes some structured group activities designed to promote interaction. The third class meeting is again separate, with an opportunity to debrief and address any issues. This format obviously takes a significant amount of class time. One potential solution is to require Inside-Out law school participants to attend a couple of class meetings before the semester begins (as do many law school clinics), or in addition to regularly scheduled class meetings. The second semester that I taught, I adopted this approach, doing some of the debriefing in additional sessions outside of regularly-scheduled class time. 
Inside-Out courses typically are organized in an interactive discussion format. ${ }^{29}$ I adapted some of these techniques for the legal curriculum. I should caveat this passage by noting that I was reluctant at first because some of these methods may seem hokey, particularly to hard-nosed law teachers. However, I can attest that they proved effective. By relieving students of the responsibility of mingling and making conversation, these formats reduced awkwardness and provided participants with a sense of security. For example, I invited my students to sit in a circle, alternating inside and outside participants-an Inside-Out technique designed to promote a non-hierarchical atmosphere and interaction between inside and outside students. $3^{\circ}$

At the beginning of the semester, as is typical in Inside-Out courses, participants developed their own guidelines for discussion. $3^{{ }^{\mathrm{I}}}$ Believe it or not, this collaborative process really did help students to maintain a collegial tone; manage conflict when it arose; and keep their comments to a reasonable length.

I also broke students into small groups to discuss specific questions and report to the larger group. For example, I might put up a quote from an opinion or from an author and ask the groups to discuss. I might ask them to parse the reasoning of an opinion in their small groups, and to explain it to one another. Or I might ask them to talk about whether they agreed with the majority or dissent in a case. I would frequently circulate to pass out readings for the following week and keep tabs on whether the groups were on track. As in a traditional classroom, I found this to be a good device for generating discussion rather than asking for volunteers in a large group in which students might feel uncomfortable. However, more than in the regular law school classroom, the small group exchanges provided an opportunity for students to engage in real dialogue about criminal justice issues.

Another technique used in Inside-Out training is to pose the same check-in question to each participant in turn at the opening of the session. I adapted this to the law course by asking a question related to the week's readings. I would ask which case or article excerpt participants most wanted to discussor which most angered or surprised them. On a number of occasions, this check-in prompted me to alter the order of my lesson plan, to take advantage of the momentum of the students' interest. For example, in the domestic violence unit in the traditional classroom, I typically begin with an excerpt from a law review article describing how domestic violence was treated in the courts in the rgth century. ${ }^{22}$ During my Inside-Out semester, however, the students overwhelmingly wanted to begin by discussing the City of Torrington

29. See, e.g., Sarah Allred, The Inside-Out Prison Exchange Program: The Impact of Structure, Content, and Readings, 6o J. Correctional Educ. 240 (2009) (concluding based on student reflection papers and feedback that the structure of the course promoted student learning).

3o. Pompa, supra note $\mathrm{I} 3$, at 72.

31. $\quad I d$.

32. See, e.g., Reva Siegel, The Rule of Love: Wife Beating as Prerogative and Privacy, I05 Yale L.J. 2 II7 (I996). 
case, 33 a milestone in the domestic violence movement, which occurred in nearby Torrington, Connecticut.

Although some Inside-Out colleagues initially questioned whether a law school class would work in an Inside-Out format, in many ways, legal courses may be a particularly effective vehicle for Inside-Out. Commentators have argued that legal education is well-suited to a carceral setting because law courses can be participatory; they help inmates to develop their analytical capacities; and they can change students' views of the law's relationship to society. ${ }^{34}$ After visiting my class, Kristin Bumiller noted the advantages of the case method. Cases are stories-they are accessible; often compelling; and, in Kristin's words, cases are "bounded," meaning that they provide students with a shared text and finite number of facts and concepts to discuss. Many of the issues in the cases are timely and relevant to both groups of students.

There were a couple of tactics that I used to make the case method more manageable for inside students. I provided a short sketch of legal doctrine as background, to a greater extent than I would in a typical upper-division law school course. I also found it useful, at least in the beginning, to call on inside students to state the facts of the case, and then to ask a law student to take the first shot at answering questions regarding legal analysis. This leveled the playing field, to an extent. Because many of our inside students read very carefully (the law students were amazed), they often had extremely detailed knowledge of the facts. A law student could then take the lead in helping us through the legal reasoning. After unpacking the legal analysis, I could ask some opinion or policy questions that would open up dialogue for all participants. That final step-the exchange of participants' views on policy choices-is the greatest comparative strength of the Inside-Out model.

\section{Benefits of Inside-Out for Law Students}

There were numerous benefits to teaching in an Inside-Out format. InsideOut is described by its founder as an "embodied" experience, and that is certainly the case. The reality of going through security and of meeting inside the facility makes an impression on law students that simply cannot be duplicated by a speaker's description, a reading, or even a film. 35

As might be expected, inside students' contributions to the discussions enriched the course. Typically, my traditional Gender \& Criminal Law seminar includes some spirited exchanges. But as in many law school courses, students tend to fall into roles for the semester-the progressive, the social conservative, the libertarian. In the Inside-Out classroom, inside students sometimes voiced counter-intuitive views, which could undermine stereotypes. Our discussion

Thurman v. City of Torrington, 595 F. Supp. I52I (D. Conn. I984).

34. Brooks, supra note 9, at 7I9, 72I, 727.

35. Nicholas de B. Katzenbach, Reflections on 6o Years of Outside Scrutiny of Prisons and Prison Policy in the United States, 30 Pace L. Rev. I446, I45 I (Fall 20IO) (suggesting that judges and law students should visit prisons). 
of cases about substance-abusing pregnant women, for example, was much more nuanced because of the presence of inside students.

Inside students sometimes also spoke about their own experiences in a way that helped us all to understand the human cost of criminal punishment policies. For example, in the traditional seminar, I assign excerpts from readings about the role of family ties in sentencing. Not surprisingly, the Inside-Out classroom discussion was much more hard-hitting than the typical abstract seminar exchange. Discussions of policing, police interrogation tactics, and parole supervision were also much richer.

Through our class discussions, the law students realized how their life experiences (and the limits of those experiences) could affect their lawyering. In a class on mothers accused of killing children, I assigned an article by Michelle Oberman that described possible circumstances that may have produced the fatal injury of a child..$^{6}$ Our discussion helped the outside students to realize that, as lawyers, they might miss key facts about a case if they rely on assumptions about clients' or victims' lives, rather than asking questions or seeking to educate themselves.

The most notable benefit of the course was one that I had not fully anticipated. It was the behavior of the law students. I have never seen law students speak or think as carefully about issues of criminal law, sentencing, and corrections policy as in an Inside-Out course. In a traditional law school classroom, in which we place a premium on the development of rhetorical skills, it is all too easy to fall into knee-jerk positions (whether law-and-order or bleeding heart liberal). In the presence of the inside students, however, law students were thoughtful and deliberate in their comments. I did not perceive that they edited themselves unduly, or avoided controversial positions. However, unlike my experience in some traditional settings, the law students refrained from making provocative remarks for the shock value alone; they listened and responded to one another rather than getting into back-and-forth exchanges to show off or score points; and they avoided glib generalizations.

\section{Applying Inside-Out in a Traditional Law School Format}

My Inside-Out experience added some new dimensions to my regular law teaching. After Inside-Out, I incorporated more participatory, interactive techniques into my traditional classroom teaching. For example, where I previously would arrive to class prepared to do a brief review and then launch into my lesson plan, I increasingly posed a question to the class about the prior lesson or the day's reading, Inside-Out style. Once I started doing this, it struck me as strange that I formerly had jumped into the day's subject matter without first taking the temperature of the class. I also found that, in contrast to the traditional Socratic Method in which one student is asked to perform while the others are permitted to tune out, asking the same question of each student both kept the pressure on by requiring a response from everyone,

36. Michelle Oberman, Judging Vanessa: Norm Setting and Deviance in the Law of Motherhood, I5 Wm. \& Mary J. Women \& L. 337 (2009). 
and took the pressure off by ensuring that no one person was singled out for interrogation.

Of course, the success of this check-in approach depends in large part on the value of the entry-point question that is posed. A concrete question about the facts will not provide much grist for discussion, and a question that is too general (e.g., "Any reactions to the readings?") will not provoke very interesting responses. I found the most effective queries to be open-ended questions that provided some focus (questions that are "ajar"). For example, I would ask what people were most excited to discuss, or whether they agreed with a particular judge's or author's view.

Another benefit of the course was indirect and not unique to InsideOut, but also worth noting. Because no electronic devices are permitted in the correctional facility, law students were not able to bring in their laptops and phones. As a result, the conversation was much more engaged. We were all in a room together-talking with one another. The novel nature of the exchange only heightened the intensity of the dialogue. Indeed, my InsideOut experience was so powerful that it has prompted me to consider banning laptops in my traditional law school classes, a position that other law teachers have championed. 37

With the support of my law school and our collaborating facility, I plan to teach a course in an Inside-Out format again in the future. I hope that other law professors will join me considering this model, and other methods for engaging incarceration in our law teaching. For more information, visit the Inside-Out web site at www.insideoutcenter.org, or contact me at gshay@law. wne.edu.

37. See, e.g., David Cole, Laptops vs. Learning, Wash. Post, Apr. 7, 2007, available at http://www. washingtonpost.com/wp-dyn/content/article/2007/04/o6/AR20070406or544.html. 